\title{
Trendsetters, Trend Followers, and Individual Players: Obtaining Global Counter-terror Actor Types from Proscribed Terror Lists
}

\begin{abstract}
This article seeks to conceptualize global counter-terror actor types by examining the designated terrorist organisations lists of six countries; the United States, the United Kingdom, Australia, Canada, Russia and China. It is argued that these countries should be placed into one of three distinct categories: Trendsetters, Trend Followers and Individual Players. Being able to classify countries according to these categories is important for global policy makers. It raises awareness of the differences between countries, and emphasises that 'one-fits-all' policies are inappropriate and have little chance of achieving global endorsement.
\end{abstract}

Key Words: Designated Terrorist Organisations, Global War on Terror, United States, United Kingdom, Australia, Canada, Russia, China, Diasporas, Regional and International Organisations.

\section{Introduction}

Since the $9 / 11$ attacks, restricting the activities of terror groups has become a global priority. Due to the perceived threat of terrorism, and in reaction to the UN Security Council's famous resolution 1373 in 2001, many countries have drawn up designated terrorist organisations lists that are used to identify which terror groups should have their assets frozen and funding resources cut off. This has created a global listing regime that many countries participate in. However, since the proscribed terrorist organisations lists have been made public, it has been shown that the security concerns and priorities of individual countries taking part in this listing regime differ. Global terror groups that create concern for some countries do not create concern for others. ${ }^{1}$ This indicates that there is no global consensus as to which groups pose the greatest threat. Therefore, a closer investigation is needed to understand the ways in which these countries differ, and why they differ in these ways. 
In the existing literature, most have focussed on the negative consequences (or lack of positive consequences) of countries including organisations on their proscribed terror lists. Haspeslagh and Santos, for example, focus on the consequences of listing terror groups during peace negotiations. They argue that the addition of terror groups to lists made by third-party actors (i.e. those who play a mediating role between conflicting parties) undermines the peace building process. ${ }^{2}$ Similarly, Turner argues that by adding armed political groups to the list of proscribed terror groups, third-party actors open the door to unwanted results, e.g. to the electoral victory of such groups in their home countries (Turner uses the US's addition of Hamas to its list as his illustrative example.). ${ }^{3}$ McCulloch and Pickering, by contrast, emphasise that including organisations on the list can have adverse effects on civil society initiatives in undeveloped countries. The inclusion of Al-Baraakat on the US's list, for example, prevented non-terrorist monetary transactions from taking place, which had the consequence of creating financial hardship for many poor local people in undeveloped countries, who relied upon these transactions for their basic needs. ${ }^{4}$ The listing regime has also been criticized for having a negative impact on human rights and academic freedoms. Many have argued that people who engage with proscribed groups may face restrictions on their fundamental rights and research liberties. ${ }^{5}$ Finally, Levi notes that the listing regime has so far been ineffective. He shows that it has had little impact on the reduction of terrorist attacks. ${ }^{6}$

The major concern of the above-mentioned studies is the negative consequences of the listing regime. However, these studies have not explored why those countries taking part in the listing regime have different perspectives when preparing their own proscribed terrorist organisations list.

The only two exceptions to the above are Phillips ${ }^{7}$ and Freedman ${ }^{8}$. According to Phillips, liberal (e.g. the US and its allies) and authoritarian (e.g. Russia and China) countries have different perceptions of global terrorism. He argues that whilst the former have prioritised eliminating terrorism at the expense of the sovereignty of countries harbouring terror groups, the latter have opposed this, emphasizing the importance of sovereignty in order to prevent the intervention of external actors in their policies that target domestic opposition (e.g. the former supported the invasion of Iraq and Afghanistan, whilst the latter opposed it, on these grounds). ${ }^{9}$ However, Phillips's study does not reveal the structural political differences that underlie the different viewpoints of the two groups of countries. 
Freedman argues that the security interests of countries such as the US, the UK, Canada, Australia, India, Russia, and international organisations such as the United Nations (UN) and the European Union (EU), differ substantially. He compares the terror lists of these six countries and two intergovernmental organisations (containing a total of one hundred twenty terrorist organisations) and identifies substantial differences between the lists. ${ }^{10}$ However, his study does not conceptualize these countries in line with their listing patterns, and so does not offer a sufficient answer to the question of how the different perceptions of these countries result in their differing lists.

In view of the lack of a study that answers the above question, this article aims to categorize international global counter-terror actors according to their listings patterns. It will be argued that it is not possible to place all countries in a single category. Instead, it will be argued that countries should be placed into one of three categories, based on their differing national interests and their global role in international affairs.

In order to conceptualize global counter-terror types this article proposes that countries should be categorised as falling into three major actor types, namely: Trendsetters, Trend Followers and Individual Players. These categories will be discussed at length in the sections that follow. But to gain an initial understanding, a brief explanation of each is apposite. Trendsetters are those countries who are most concerned with, and most vocal about, global terrorism, and who have a great influence on which terror groups are included on the lists of other countries. Trend Followers are those countries who have less concern about global terrorism, and who are most influenced by the Trendsetters in drawing up their lists. Individual Players, by contrast, are those countries who have little concern about global terrorism, but are concerned with indigenous or regional terrorist organisations.

The data used in support of the proposed categorisation are gathered from the publicly available terrorist organisations lists of six countries (the US, the UK, Australia, Canada, Russia, and China). One-hundred-and-seven terror-related groups appear on at least one of the lists of these countries. In order to determine global counter-terror actor types, these groups were cross-checked with each of the proscribed lists of the above-mentioned countries. The lists were obtained from the governmental web pages of each country. ${ }^{11}$ As for US, this article only makes use of the Foreign Terrorist Organisations List (FTOs), and not 
the Terrorist Exclusion List (TEL), as the latter list is prepared for immigration purposes only. The lists of the UN and the EU were also excluded due to their intergovernmental nature. A summary of all the data utilised from the proscribed terror lists of the six countries is given in an appendix.

In this article a variety of terms are used more-or-less interchangeably: proscribed 'terror groups', 'terror organisations', and 'armed groups'. These terms are used to refer to the groups that appear on the proscribed lists of the six counties mentioned above. However, it should be noted that this merely reflects the fact that these groups appear on the lists of the six countries. It is not the concern of this article to assess whether these groups should have been placed on these lists and labelled as being terrorist groups. So, whether the countries involved are justified in conceiving of the groups on their lists as terrorist groups is left as an open question. This study is as a tentative first attempt at categorizing global counter-terror actor types, as the categories have been framed based on the evidence available from only six countries. This is an unavoidable limitation of this study because at the current time there are no other comparable data sets publicly available. Some countries (e.g. France) have no publicly available list at all, whilst others (e.g. India) have lists available but they are lacking in crucial details that this study makes use of (e.g. there is no information available about when the terrorists groups were added to India's list). If and when the lists of further countries become available, it may be that other countries fit directly into the categories outlined here. But it may also be that the categories, and the criteria used to define them, will need alteration, and perhaps it will be necessary to add new categories. Nevertheless, because of the generality of the categories outlined here, it is likely that the core elements of each category will remain. So further work is likely to build upon the groundwork laid down in this article, rather than supplant it.

In the next section the historical background of the listing regime is outlined. It is followed by a section in which the concepts of Trendsetters, Trend Followers, and Individual Players are summarized. The section following categorizes the above-mentioned six countries in light of these three global counter-terror actor concepts. (Unreferenced claims made in this section are based on the data provided in the appendix.) In the concluding section, the outcome of the empirical investigation is evaluated and further research suggestions are made. 
The final publication is available at Springer via http://dx.doi.org/10.1080/1057610X.2014.974400

\section{Background of Listing}

Prior to the 9/11 attacks, some countries were already making use of proscribed terrorist organisations lists, drawn up based on domestic legislation. For instance, the UK included the Provisional Irish Republican Army in its list in 1989, based on its Prevention of Terrorism (Temporary Provisions) Act $1989 .{ }^{12}$ The US also made use of the listing procedure, starting in 1997, due to the increasing suspicion in the US that terrorist threats from abroad were imminent ${ }^{13}$ It added terrorist organisations which had attacked US targets to its list by relying on its Immigration and Nationality Act. ${ }^{14}$

The first steps towards a global listing regime started with the UN resolution $1267 .{ }^{15}$ This resolution established a sanctions committee that focussed on imposing sanctions and freezing the assets of Al-Qaida and the Taliban. All states were urged to impose these sanctions and report their activities to the Committee. ${ }^{16}$ After the 9/11 attacks in 2001, however, the UN Security Council released its resolution 1373, in which it urged all member countries to freeze the funds and assets of all terrorist organisations. ${ }^{17}$ Unlike resolution 1267 the scope of the sanctions committee was no longer limited to Al-Qaida and the Taliban. It encouraged every country to submit any individual and any terrorist organisation to the Committee's consolidated list. ${ }^{18}$

Since the adoption of resolution 1373, many UN member countries have issued their national proscribed terrorist organisations lists. By examining these lists, it has become easier to evaluate each of these countries' threat perceptions. However, contrary to expectations, the security concerns of countries do not overlap with each other. ${ }^{19}$ This indicates that different countries perceive the threat of terrorism differently, and draw up their lists based upon differing considerations. Building upon this evidence, it will be argued in this paper that the different countries are best classified into three groups: Trendsetters, Trend Followers, and Individual Players. Being able to classify countries according to these categories is important for global policy makers. It raises awareness of the differences between countries, and emphasises that 'one-fits-all' policies are inappropriate and have little chance of achieving global endorsement.

In what follows a description of each of the categories is given, and in light of each, a set of five conditions is laid down that a country must meet if it is to be classified as falling 
into it. However, due to the complex nature of global politics, these sets of conditions should not be viewed as constituting strict necessary and sufficient conditions for membership in each category. If a country clearly satisfies at least four conditions within a given set, then so long as it does not clearly fail to meet the remaining condition, it is classified as falling into the given category.

\section{Conceptualizing Trendsetters}

Trendsetters exert a significant influence on the global listing regime. They have political and economic interests that extend to all regions of the world. Their extensive interests often conflict with the local political conditions in other countries and they are often targeted by foreign terrorist organisations. In line with their broad political and economic activities, the number of terrorist groups attacking these countries is considerably higher than in other countries, and so is the number of terror groups proscribed by them.

Trendsetters are developed countries where living standards are comparatively better than other states in terms of individual freedoms and economic benefits. As a consequence, these countries host many diasporas affiliated with terrorist groups, who immigrated from other countries due to escalating violence and poor economic conditions. ${ }^{20}$ By relying on the democratic environment provided by them, some diasporas use Trendsetter countries for fund-raising, recruitment, and to disseminate their political propaganda both inside and outside of the host country. ${ }^{21}$ Although some terrorist organisations supported by these diasporas in Trendsetter countries do not pose major security risks for Trendsetters themselves, they are proscribed due to the threat they pose to other countries (perhaps in consideration of the risk that they will pose a future threat to themselves). ${ }^{22}$

Trendsetters also shape the agenda and norms of international and regional organisations. They promote their own interests and impose requirements upon other countries by utilizing these organisations to create globally binding rules. In order to achieve these objectives, they also provide incentives to, and impose sanctions on, other countries. ${ }^{23}$ They also encourage their allies to comply with the norms that develop around the listing regime (e.g. those laid down in UN resolution 1373) in order to increase its efficiency. ${ }^{24}$ 
Trendsetters also play a major role in influencing like-minded countries in the drawing up of their proscribed terror lists. ${ }^{25}$ Despite the fact that some terror groups do not pose a security threat to the allies of Trendsetters, the latter countries are motivated by the Trendsetters to include them in their lists. ${ }^{26}$ This is to indicate solidarity with the Trendsetter countries in order to be part of a strong international coalition. In particular, the allies of Trendsetters often add terror groups to their lists following the addition of them to the lists of Trendsetters themselves.

Finally, Trendsetters also sometimes base their listing decisions on the threat assessments of their close allies and for diplomatic reasons ${ }^{27}$ That is, they often add terrorist organisations to their lists in order to indicate solidarity with their allies, or as a good-will gesture to rival countries, i.e. in order to achieve better economic and political relations with them.

In summary, Trendsetter countries are those that satisfy the following conditions:

1. They have a high level of political and economic influence at the global level, and are targeted by a high number of foreign terrorist organisations because of the influence they exert.

2. They host a high number of diasporas that support terrorist groups outside of their territories, and are concerned with the threat they pose to other countries.

3. They play a leading role in international and regional organisations, and as a consequence have a high level of influence on the global listing regime and shaping global norms (i.e. their decisions about which terror groups are proscribed effect the decisions of other like-minded countries, either directly or via the establishing of global norms).

4. As a consequence of 3 , they are often the first to add global terror groups to their proscribed lists, and other countries often follow.

5. They are often motivated to add terror groups to their lists in order to indicate solidarity with their allies, or to foster relationships with their rivals. 


\section{Conceptualizing Trend Followers}

Trend Followers are not as strong or influential as Trendsetters in global politics, and their political and economic activities have a narrower scope. Due to their moderate or sometimes weak impact, these countries are not often targeted by terrorist organisations, either in their homeland or abroad. They attach less priority to terrorism in comparison to Trendsetters. Therefore, they have comparatively limited influence on setting trends in the listing regime.

Like Trendsetters, Trend Followers provide a fertile political and economic environment to diasporas, some of who support armed groups involved in terrorist attacks. These diasporas are formed in Trend Follower countries by individuals who have escaped from escalating violence in their homeland caused by clashes between government forces and terror affiliated groups. ${ }^{28}$ Because the living conditions and the democratic circumstances in Trend Follower countries is better than in their home countries, diasporas in these countries sometimes support terror groups in their home countries by providing remittance funds, new recruits, and by using lobbying activities to seek political support. ${ }^{29}$ Although terror groups supported by these diasporas often have no intention to harm Trend Followers themselves, those groups are often proscribed out of a general concern with countering global terrorism (perhaps further motivated by the decisions of Trendsetters and due to the fear that they will pose future security risks). ${ }^{30}$

In comparison to Trendsetters, Trend Followers are not in a strong position to exert influence on international and regional organisations. Therefore, they do not have a determining role on the global counter-terror listing regime. They mostly follow the decisions of Trendsetters in order to avoid contradicting the decisions of these powerful actors, and they also often echo the rhetoric of the regime created by the Trendsetters. ${ }^{31}$ By doing so, they shield themselves from the negative consequences of opposing Trendsetters, and show that they are in solidarity with them. ${ }^{32}$

Trend Followers mostly follow the listing trend of Trendsetters. They generally add terror groups to their lists after they are added by Trendsetters. Again, although some terror groups on the lists of Trend Followers do not pose any threat to these countries themselves, they are motivated by the decisions of Trendsetters and the possibility of facing attacks from similar terrorist organisations. ${ }^{33}$ 
In summary, Trend Follower countries are those that satisfy the following conditions:

1. They have a medium or low level of political and economic influence at the global level, and are targeted by a low number of foreign terrorist organisations.

2. They host a high level of diasporas that support terrorist groups outside of their territories, and are concerned with the threat they pose to other countries.

3. They play more of a following role in international and regional organisations, and so have a low level of influence on the global listing regime.

4. As a consequence of 3 , they are not usually the first to add global terror groups to their proscribed lists, and instead often follow the listing patterns of others.

5. There is no clear evidence either way about whether they add terror groups to their lists to indicate solidarity with their allies, or as a good-will gesture to their rivals (except insofar as they indicate solidarity with Trendsetters by following them).

\section{Conceptualizing Individual Players}

Individual Players may be equally as strong as Trendsetters in influencing global politics, or they may have a minor influence. However, due to their greater focus on internal affairs and their comparative unwillingness to alter the political and economic policies of countries outside of their immediate region, they tend to be protected from being targeted by global terror groups. Consequently, they are mostly targeted by indigenous or regional terrorist organisations, and so the number and diversity of terrorist groups proscribed by these countries is not as great as that of Trendsetters.

Individual Players are not attractive to diasporas with links to terror groups, for two reasons. The first reason is to do with the economic conditions within Individual Player countries. The average per capita income is lower than in wealthy Trendsetter and Trend Follower countries. Those who set up diasporas do not seek immigration to these countries, because of limited job opportunities and low wages. This also weakens the opportunities to raise funds for terrorist groups. Therefore, Individual Players do not provide a suitable environment for diasporas. On the contrary, those who sympathise with the indigenous terror groups of these countries often seek immigration to Trendsetter and Trend Follower countries instead. The second reason is to do with the democratic conditions within Individual Player countries. They often have authoritarian or illiberal democratic practices and so 
publicity and lobbying opportunities for diasporas to disseminate propaganda is limited. So, in the absence of a fertile economic and political environment, diasporas are attracted to Trendsetter and Trend Follower countries, rather than Individual Player countries.

Some Individual Players have a strong position in international organisations. However, they utilize these institutions to a lesser extent than Trendsetters, and do so mainly in order to further their own security interests. Therefore, the influence they exert through the use of international organisations is considerably weaker than the influence of their rivals in determining the direction of the listing regime. This is not to say that these countries do not use their power in international and regional organisations in a way that frustrates the will of Trendsetters. They often do so in order to block the mandates of dominant states in the counter-terror domain, and to defend their self-interest. ${ }^{34}$ They often also challenge the counter-terror initiatives of Trendsetters by seeking the support of other states who also oppose the views of Trendsetters. In order to do so, they use informal negotiation channels, and much broader institutions of international organisations, which enables weak states to have a say (e.g. the UN General Assembly). ${ }^{35}$

Terrorist organisations who pose a security threat only to other countries, are not a concern for Individual Players. Global terror organisations are only added to the lists of such countries when they also pose a threat to their own security. ${ }^{36}$ In this respect, Individual Players do not act like Trendsetters; they do not have the view that fighting terrorism requires a global response. ${ }^{37}$ They also differ from Trend Followers in this respect; they are not heavily influenced by the decisions of like-minded states or their allies. Furthermore, these countries have little concern with showing solidarity with their allies, or with making a gesture to their rivals for better relations.

In summary, Individual Player countries are those that satisfy the following conditions:

1. They have a high, medium, or low level of political and economic influence at the global level, but are targeted by a small number of foreign terrorist organisations.

2. They host very few, if any, diasporas that support terrorist groups outside of their territories, and are unconcerned with the threat those groups pose to other countries. 
3. Their motives in international and regional organisations are more ambiguous. They primarily involve themselves with such organisations for their own benefit, and are often willing to subvert their processes where they conflict with their interests.

4. As a consequence of 3 , they neither lead nor follow the listing patterns of other countries.

5. They seldom, if ever, add terror groups to their lists to indicate solidarity with their allies, and to foster relationships with their rivals.

\section{Trendsetter Countries}

\section{United States}

The US has a pioneering role in the international order. Its presence in many countries and its hegemonic motives provokes many terror groups from around the world. It creates a common desire among terror groups to overthrow US mandates, interests, and influence. ${ }^{38}$ US targets are attacked by various terrorist organisations both at home and abroad. ${ }^{39}$

According to the US terror list, it has been targeted by thirty-three different foreign terrorist organisations abroad, and one foreign terrorist organisation at home. It has also been targeted by Al-Qaida both at home and abroad. US citizens, embassies, military bases, military personnel, US based aid groups, tourists, and Christian missionaries were the focus of these attacks. ${ }^{40}$ This shows that the US clearly satisfies the first Trendsetter condition.

The political and economic conditions in the US are also suitable for diasporas that fund terror groups. The Irish diaspora funded the Provisional Irish Republican Army (PIRA), the Shi'ite diaspora funds Hezbollah, the Palestine diaspora funds Hamas, and the Sri Lankan diaspora funded the Liberation Tigers of Tamil Elam (LTTE). This provides a few examples that show the links between diasporas located in the US and their engagement with terror groups. ${ }^{41}$ Even though these groups are not a major threat to US interests ${ }^{42}$, they are proscribed by the US authorities in consideration of their activities financing terrorism. The US can therefore be seen to clearly satisfy the second Trendsetter condition. They not only proscribe terror groups which inflict damage to US interests, but also groups that harm other countries by exploiting liberal political and economic opportunities in the US. 
The US also has a great impact on international and regional organisations. The US is one of the permanent members of the UN Security Council (UNSC) and the UN Resolution 1373 was led by the US. ${ }^{43}$ It also framed the Financial Action Task Force (FATF) counterterrorist financing measures with the UK, and it persuaded other members to adopt them. ${ }^{44}$ After the 9/11 attacks, the US sought to promote its anti-terror measures to Asian-Pacific Economic Cooperation (APEC) countries. ${ }^{45}$ Furthermore, it succeeded, with the support of the G-7 countries, in passing the UN Convention for the Suppression of Terrorist Financing. ${ }^{46}$ So the US can also be seen to clearly satisfy the third Trendsetter condition; it has a major influence on regional and international organisations, and plays a major role in setting the agenda for the listing regime.

The addition of most terror groups on the US list came before their addition to the lists of like-minded states such as Australia and Canada. According to the proscribed terrorist organisations lists given in the appendix, fourteen terrorist organisations were proscribed by the US at an earlier date than they were proscribed by both of these other countries. Furthermore, these groups have mostly targeted US interests rather than Australian and Canadian interests. In this respect, the US is a leading figure for both countries, and so can be seen to clearly satisfy the fourth Trendsetter condition.

The US often designates terror related groups for diplomatic reasons. The proscribed groups on its list that do not threaten its own interests are a threat to the domestic governments of its allies or rivals. ${ }^{47}$ The addition of Euskadi Ta Askatasuna (ETA) for Spain, Caucasus Emirate for Russia ${ }^{48}$, Hamas and Hezbollah for Israel ${ }^{49}$, are all important examples that the US listing pattern is also shaped by its desire to foster relations with other countries. So the US also clearly satisfies the fifth and final Trendsetter condition.

The US clearly satisfies all Trendsetter conditions, and so should be regarded as falling into this category.

\section{United Kingdom}

Despite the fact that the global political and economic impact of the UK is not as dominant as that of the US, it is one of the US's strongest allies. Moreover, this relationship has been extended with regards to countering terrorism since $9 / 11 .{ }^{50}$ Because the UK shares the same coalition with the US in the 'Global War on Terror', and because it advocates similar counter- 
terror measures against terrorist organisations, the UK has become a prime target for many foreign terror groups. ${ }^{51}$ According to the UK's terrorist organisations list, it has been targeted by fifteen foreign terrorist organisations abroad, by twelve indigenous terrorist organisations at home, and by two foreign terrorist organisations (Al-Qaida and Abu-Nidal) both at home and abroad. In view of the fact that a total of seventeen foreign terrorist organisations have targeted the UK, the threat of terrorism extends beyond its borders. Various terrorist groups from different parts of world see the UK and its citizens as a target for their political cause. So, the UK clearly satisfies the first Trendsetter condition.

The UK has also provided suitable liberal economic and political conditions for diasporas who have links with terrorist organisations. The diasporas in the UK supply a considerable amount of regular remittance to the armed groups in their homeland. ${ }^{52}$ The Tamil diaspora supported the LTTE ${ }^{53}$, the Kurdish diaspora helps the Kurdistan Workers Party $(\mathrm{PKK})^{54}$, and the Lebanese communities raise funds for Hezbollah. ${ }^{55} \mathrm{All}$ of these are significant examples of this linkage. These groups are not a major threat to the UK itself, so the proscription of these groups by the British authorities reveals that countering terrorism is much more than a domestic issue for the UK. So the UK clearly satisfies the second Trendsetter condition.

The UK, like the US, has a major role in international and regional organisations. It is one of the permanent members of UNSC and acted together with the US by initiating the listing regime. ${ }^{56}$ The UK was one of the countries, along with the US, who promoted counterterror financing measures in the FATF after the 9/11 attacks, and has been monitoring its implementation in other countries. ${ }^{57}$ It is also an influential actor in the EU. When the EU counter-terror strategy was adopted in 2005 , the UK Presidency in the EU played a vital role in its preparation. ${ }^{58}$ Furthermore, the EU directives regarding monitoring migrant remittances (which is an important part of fund-raising for terrorist organisations) was first framed and adopted in the UK, and only later adopted by the EU. ${ }^{59}$ The UK also had a central role on the proscription of some organisations by the EU, such as the People's Mojahedin Organization of Iran (OMPI). ${ }^{60}$ So the UK clearly satisfies the third Trendsetter condition.

The UK does not clearly satisfy the fourth Trendsetter condition, but it does not clearly fail to satisfy it either. The UK proscribed eight terror groups earlier than Canada and 
Australia, but proscribed four later. In this respect, the UK's role in influencing other countries is not as notable as that of the US. However, due to the fact that a high percentage of countries were first proscribed by the UK, it at least partially satisfies the condition.

The UK also proscribes many terror groups in order to support its allies. For instance, the UK was the first country amongst the European countries to add the PKK to their terror list ${ }^{61}$, despite the fact that the PKK has not been a major threat to UK security. The motivation for adding the PKK to the UK list was to support Turkey's right to defend itself against terrorism. ${ }^{62}$ Also, the military wing of Hamas and Hezbollah was proscribed by the UK in order to foster close UK-Israel relations. ${ }^{63}$ In consideration of these examples, it can be seen that the UK clearly meets the fifth Trendsetter condition.

The UK fully satisfies the first, second, third, and fifth Trendsetter conditions, and at least partially satisfies the fourth. So the UK should be viewed as falling into this category along with the US.

\section{Trend Follower Countries}

\section{Australia}

Since World War I Australia has been one of the US's and UK's strongest and most faithful allies. After the Bali Bombings in 2002, where eighty-eight Australians were killed, this relationship became even closer within the context of counter-terrorism. ${ }^{64}$ However, Australia has not suffered any terrorist attacks in its own territory since the 1986 attack against the Turkish Consulate by Armenian terrorists. ${ }^{65}$ Furthermore, despite the fact that more than one-hundred Australians have been killed in terrorist attacks abroad since the 9/11 attacks $^{66}$, and the fact that its embassy in Jakarta was targeted by terrorist groups in $2004^{67}$, Australia has been a low-profile target for foreign terrorists groups. ${ }^{68}$ Australia has faced an increased terror risk since the $9 / 11$ attacks, but the reason for this is due to its contribution to the US led war on terror in Iraq and Afghanistan, rather than any global policy that it has initiated itself. ${ }^{69}$

That Australia is not one of the main targets for foreign terrorist groups is reflected in its listing pattern. Australia's list contains eighteen terror groups. Only six of these groups have led attacks which have resulted in the death of Australian citizens, but most of the 
victims were Australian tourists on vacation targeted for their Western identity rather than for being citizens of Australia. The other twelve groups have not led any attacks that have involved Australian citizens or entities, either at home or abroad. As such, Australia has been the target of very few direct attacks by foreign terrorists. So, Australia can be seen to clearly satisfy the first Trend Follower condition.

Australia's strong economy and long democratic tradition are attractive to diasporas. ${ }^{70}$ These diasporas transfer remittance and donations collected by its members who are sympathetic to terror related organisations. ${ }^{71}$ The Tamil diaspora raise funds for the Tamil Tigers $^{72}$, the Lebanese diaspora supports Hezbollah ${ }^{73}$, and the Filipino and Indonesian diasporas raise funds for Jemaah Islamiyah ${ }^{74}$. All are noteworthy examples of why Australia is interested in suppressing the financing of terrorism, despite the fact that it has not been under serious terrorist threat from these groups in its territory. So, Australia clearly satisfies the second Trend Follower condition.

Australia's impact in international and regional organisations with regards to the listing regime and combating terrorism is not as prominent as countries such as the UK and the US. Even though it takes part in regional counter-terrorism cooperation with countries such as China, India and the Southeast Asian states ${ }^{75}$, it does not have a pioneering role. It has little influence over the decisions made by these countries to proscribe terror groups, and little influence on their counter-terrorism policies. Furthermore, because Australia generally echoes US arguments and supports US global counter-terrorism strategies, its influence on Asian and Pacific countries is undermined; it gives the impression of pursuing US regional interests rather than its own political agenda. ${ }^{76}$ In addition, even though it is not a permanent member of UNSC, Australia also automatically adds persons and entities to its list once they are added to the list of the UN Sanction Committee. ${ }^{77}$ In view of these factors, Australia clearly satisfies the third Trend Follower condition.

Thirteen terror groups listed by Australia are also listed by the UK and the US. Of these, only one was added by Australia first (Ansar al-Islam). Twelve were previously added by the US, and eight by the UK. In this respect, Australia's listing pattern is heavily influenced by the threat perceptions of its overseas partners. So, Australia can be seen to clearly satisfy the fourth Trend Follower condition. 
The final publication is available at Springer via http://dx.doi.org/10.1080/1057610X.2014.974400

Unlike in the case of the US and the UK, there is no evidence that Australia is motivated to add terror groups to its list in order to indicate solidarity with other countries except for the Trendsetters. Therefore, it clearly satisfies the fifth Trend Follower condition.

Australia clearly satisfies all five Trend Follower conditions, and so should be classified as falling into this category.

\section{Canada}

Canada has experienced a number of terrorist attacks in the past. There was separatist terrorism (Front de Liberation du Quebec) in its territory during the $1960 \mathrm{s.}^{78}$ In the $1980 \mathrm{~s}$ there were also international terrorist attacks. Turkish diplomats were targeted by Armenian terrorist organisations (viz. the Armenian Secret Army for the Liberation of Armenia (ASALA), the Justice Commandos of the Armenian Genocide (JCAG), and the Armenian Liberation Army $(A L A)$ ), and Sikh militants (Babbar Khalsa International) were involved in the bombing of Air India Flight 182, which resulted in the death of two-hundred-and-eighty Canadian citizens (mostly from South Asian Origin). ${ }^{79}$ However, since then, despite a few low-scale terrorist plots involving Al-Qaeda, and except for a few isolated incidents involving Canadian tourists and business people (who, as in the case of Australia, were targeted for their Western identity rather than being citizens of Canada), Canada has little experience of terrorism, either foreign or indigenous.

Canada has also positioned itself as a peacekeeper country in the international society, and has focused on promoting peace, human rights, and human security in regions of conflict. ${ }^{80}$ Therefore, unlike countries such as the UK and the US, it has been targeted by a small numbers of foreign terrorist groups. There are forty-one groups in its proscribed terror list. Of these, only nine have led attacks that have resulted in the death of Canadian citizens, and of these nine, eight were attacks abroad that involved tourists on vacation, and only one (Babbar Khalsa International) attack occurred at home. The other thirty-two groups on its list have not been involved in any terrorist activities against Canada. So, Canada clearly satisfies the first Trend Follower condition.

Many diaspora's exist in Canada and provide financial support to global terror groups outside of Canada through donations, money laundering, drug trafficking, and smuggling. ${ }^{81}$ Diasporas associated with armed groups, such as the Sikh diaspora associated with armed 
groups in India ${ }^{82}$, the Tamil diaspora associated with the LTTE $^{83}$, and the Lebanese Shi'te diaspora associated with Hezbollah ${ }^{84}$, use or used Canadian territory to fund the operational income of these groups. Although these groups have not been involved in any act of terrorism against Canadians, their activities are not tolerated in Canada. Canada lists terror groups supported by diasporas in its territory out of a general concern with countering global terrorism, and therefore clearly satisfies the second Trend Follower condition.

Canada does not clearly satisfy the third Trend Follower condition, but it does not clearly fail to satisfy it either. Canada has a moderate role in international and regional organisations, and so a moderate influence on the global listing regime. On the one hand, it has led some global terror initiatives. It initiated the establishment of headquarters for the Egmont Group of Financial Intelligence Unit (FIU) in Canada. ${ }^{85}$ This informal network provides a forum for member countries to improve cooperative efforts in the fight against financing terrorism. On the other hand, it has merely mirrored the policies of others. After the 9/11 attacks, it expressed its immediate solidarity with the US, and followed its lead in enacting national suppression of financing of terrorism laws, in blacklisting terrorist groups, and in pursuing container security measures. ${ }^{86}$ Despite the fact that Canada's role in setting the international agenda on global terrorism is mixed, the fact that it often plays a follower role in such matters means that it does not clearly fail to satisfy the third Trend Follower condition.

Canada has also added many terrorist groups to its list following the decision of Trendsetter countries to do likewise. Of the eighteen terror groups proscribed by Canada, the US, and the UK, all eighteen were added by Canada following the US, and fourteen following the UK. So Canada clearly satisfies the fourth Trend Follower condition.

As is the case with Australia, there is no evidence that Canada is motivated to add terror groups to its list in order to indicate solidarity with other countries except for the Trendsetters. Therefore, it clearly satisfies the fifth Trend Follower condition.

Canada clearly satisfies the first, second, fourth, and fifth Trend Follower conditions, and does not clearly fail the third. So, Canada should be classified as falling into this category. 


\section{Individual Player Countries}

\section{Russia}

Russia is one of the most important international actors in world politics due to its diplomatic and geographical influence, its nuclear, military, and intelligence capacities, and due to it being an important energy supplier. ${ }^{87}$ Moreover, during the Cold War it shared its superpower role with the US, and since the end of the Cold War it has gained a gradually increasing influence over post-Soviet Union states. However, despite the Russian interest in many regions in its vicinity, the number of terrorist organisations that pose a threat to Russia's interests is small compared with countries like the UK and the US.

There are eighteen proscribed terror groups on Russia's terror list. Two of these groups are indigenous and have targeted Russia both at home and abroad (especially active are Chechen armed groups). The remaining sixteen groups are foreign terror groups, but only five of them have been responsible for attacks on Russia, and only then abroad. Russia has thus been targeted by relatively few foreign terror groups, and thus clearly satisfies the first Individual Player condition.

Russia is not a popular destination for diasporas. On the contrary, those Russians active in diasporas have taken refuge in other countries. For instance, Russia has taken a hardline counter-terror approach towards Chechen militants and civilians. It has violated their human rights and evacuated Chechen settlements, causing a significant number of Chechens to emigrate to regions close to Russia ${ }^{88}$ and other European countries including Austria, Belgium, Norway, France and the Netherlands. ${ }^{89}$ Due to the lack of diasporas in Russia, it clearly satisfies the second Individual Player condition.

Although Russia is active in international organisations in the context of counterterrorism, its motives are ambiguous. Russia, like the US and the UK, is one of the permanent members of UNSC. Furthermore, it is a leading counter-terror figure in regional organisations such as the Common Wealth of Independence States (CIS) and the Shanghai Cooperation (SCO). It is also engaged in bilateral counter-terror cooperation with countries such as the US and India..$^{90}$ However, Russia's desire to cooperate when dealing with counter-terror issues is mainly based on its self-interest. Its main motivations for supporting the US initiated global war on terror are to allay Western suspicions that Russia is not a reliable counter-terror 
partner and in fact follows its own agenda ${ }^{91}$, to counter-balance increasing US presence in Central Asia ${ }^{92}$, and to justify its hard-line counter-terrorism strategy against Chechen groups. ${ }^{93}$ Furthermore, Russia and its allies in the SCO (e.g. China) have not cooperated with Trendsetter countries (such as the US and the UK) when their national priorities are at stake. ${ }^{94}$ Russia therefore clearly meets the third Individual Player condition.

Every foreign terrorist group added to Russia's list has been added at a later time than they were added the lists of the US and the UK, so Russia cannot be viewed as leading the listing patters of other countries. But neither can it be seen as following. Russia has not added these groups to its list based on the decisions of Trendsetter countries, but has added them for autonomous self-interested reasons. This can be seen by noting that Russia only adds terror groups to its list when they pose a domestic terror threat, and is reluctant to add groups to their list that do not pose such a threat. ${ }^{95}$ For example, the Egyptian Islamic Jihad, Al-Gama al-Islamiyya and the Muslim Brotherhood were all added because they support Afghan Jihad against the Soviet Union invasion in Afghanistan, and they raise funds for Chechen groups. ${ }^{96}$ Russia has also refrained from adding armed groups such as the ETA, the PKK and the LTTE, which are recognized as being terrorist organisations by many other countries, including the US and the UK. These groups have based their campaign on Marxist principles, and Russia seems to be reluctant to blacklist these groups because of their links with the Soviet Union's heritage. So Russia clearly meets the fourth Individual Player condition.

Russia is also reluctant to add other terror affiliated groups to indicate solidarity with its allies, or as a good-will gesture to its rivals. The above-mentioned Egyptian groups are major threats to Egypt, rather than Russia. But as has already been seen, these were not added to indicate solidarity with Egypt, but were added, rather, due to the threat they pose to Russia itself. In addition, despite the fact that China is a strong ally of Russia's against the Western Coalition (US, UK, France), the groups considered as terror groups by China and Russia have no overlap at all. As such, Russia also clearly satisfies the fifth Individual Player condition.

Russia clearly satisfies all five Individual Player conditions, and so should be classified as falling into that category. 


\section{China}

China is a rising power with a rapidly growing economy, and an increasing impact on regional and global. ${ }^{97}$ However, despite its expanding regional/global political influence, and despite the fact that a large population of Chinese workers and engineers exists outside of China, China and its citizens are rarely targeted by foreign terrorist groups. ${ }^{98}$ China's proscribed terror list is very limited; there are only four groups on its list. Each is indigenous, connected specifically with Uighur minorities who are seeking autonomy/independence in China's Xinjiang province. So China is targeted by no foreign terror groups, and so clearly satisfies the first Individual Player condition.

China, like Russia, is not an attractive country for diasporas. The economic opportunities for fundraising and the democratic environment for disseminating propaganda are poor compared with Trendsetter and Trend Follower countries. Indeed, minorities in China such as Uighurs seek refuge in other countries for their political cause. They have spread to many countries including the US, Germany, Turkey, and Saudi Arabia. ${ }^{99}$ So there are no diasporas in China, and so it also clearly satisfies the second Individual Player condition.

As a permanent member of UNSC, China is one of the strongest political actors in the UN. Furthermore, it has been in close counter-terror cooperation with countries such as Russia, Tajikistan, Kazakhstan and Kyrgyzstan, under the SCO framework. However, China's global counter-terror motives in international and regional organisations are not based on achieving international peace and security. They are based, rather, on its self-interest, specifically in maintaining its position within the global power equilibrium. After the 9/11 attack, along with its close ally Russia, it initiated SCO counter-terrorism cooperation in order to counter-balance the impact of the US on Central Asian countries. ${ }^{100}$ It also collaborated with weak states in the UN in order to create an international consensus regarding the rights of sovereign states to veto interventions made by the US in the name of the global war on terror. ${ }^{101}$ Furthermore, China has sought to take advantage of counter-terror initiatives made by international organisations in order to justify its policies against domestic opposition and separatist movements. ${ }^{102}$ So China clearly satisfies the third Individual Player condition.

Little needs to be said to show that China clearly meets the fourth and fifth Individual Player conditions. Foreign terrorist organisation such as Al-Qaida, recognized by almost every 
country as a terrorist organisation, is not on China's list. In this respect, China's listing pattern is solely focused on domestic secessionist movements rather than global terror threat. ${ }^{103}$ In addition, the terror groups that are on its list are all separatist groups that are viewed as posing a threat to its territorial integrity. None of them are contained on any of the lists of other countries. Even China's close ally Russia does not perceive these groups as terror groups. So China clearly follows its own agenda; it is unconcerned with the terror threat faced by other countries, it follows no other country, and no other country follows it.

China clearly satisfies all five Individual Player conditions, and so should be classified as falling into that category.

\section{Conclusion}

This article has demonstrated that there is no common understanding regarding the global war on terror. There are distinct global counter-terrorism actor types, each of which have their own distinctive perceptions about countering terrorism, which are reflected in their listing patterns. In light of this, this study conceptualizes three global counter-terror actor types. The first group, the Trendsetters, has been shown to include the US and the UK. These are influential countries that export their counter-terrorism initiatives to like-minded countries. The second group, the Trend Followers, has been shown to include Australia and Canada. These are mimetic actors those transpose the counter-terrorism initiatives of Trendsetter countries to their own countries. The third group, the Individual Players, has been shown to include Russia and China. They are only concerned with their own security, and share little common ground with either Trendsetter or Trend Follower countries.

In view of these findings, Trendsetter and Trend Follower countries have the ability to act together against a terror threat even when that threat is not a direct threat to one of those individual countries itself. However, Individual Players are not interested in countering the threat of terrorism when it does not pose a direct threat to themselves. Therefore, the chances of being able to frame a single counter-terrorism policy that requires all countries to participate in order to be effective, are very low. Unless all countries view the war on terror from the same perspective as the Trendsetters or the Trend Followers, a truly global war on terror is simply not possible. Even if a terror threat were a threat to all countries, including 
the Individual Player countries, a unified response would only succeed so long as the threat remained a threat for the Individual Players.

It is important to note that the current conclusion applies only at the current time and in the current global conditions. It is possible that over time, as conditions change, a country that currently satisfies the conditions of one category may come to satisfy the conditions of another. For instance, it is possible for an Individual Player country to gain Trendsetter features, e.g. if it begins to gain a greater influence on other countries, or if it becomes concerned with the threat of terrorism in countries other than its own.

This study is a preliminary contribution to conceptualizing global counter-terror actor types. It may be that these concepts can be applied directly to other countries if and when their designated terrorist organisations lists become publicly (or otherwise) available. However, as the number of lists available increases, some modification of the categories may be necessary, and it may perhaps be necessary to add new categories. This should be viewed in a positive, rather than a negative light, however. The concepts laid down in this article, or the concepts that develop from them, will gain ever greater validity as more lists are examined, and more studies in this area are conducted.

\section{Endnotes}

\footnotetext{
${ }^{1}$ Benjamin Freedman, "Officially Blacklisted Extremist/Terrorist (Support) Organisations: a Comparison of Lists from Six Countries and Two International Organisations " Perspectives on Terrorism 4, no. 2 (2010),pp.46-52.

${ }^{2}$ Sophie Haspeslagh, "Listing Terrorists: The Impact of Proscription on Third-Party Efforts to Engage Armed Groups in Peace Processes - a Practitioner's Perspective," Critical Studies on Terrorism 6, no. 1 (2013).pp.189208; Soliman Santos, "Counter-terrorism and Peace Negotiations with Philippine Rebel Groups," Critical Studies on Terrorism 3, no. 1 (2010), pp. 137-154.

3 Mandy Turner, "Building Democracy in Palestine: Liberal Peace Theory and the Election of Hamas," Democratization 13, no. 5 (2006), pp.739-755.

${ }^{4}$ Jude McCulloch and Sharon Pickering, "Suppressing the Financing of Terrorism Proliferating State Crime, Eroding Censure and Extending Neo-Colonialism," The British Journal of Criminology 45, no. 4 (2005), pp.470486.

${ }^{5}$ Alex Conte, Human Rights in the Prevention and Punishment of Terrorism Commonwealth Approaches: United Kingdom, Canada, Australia and New Zealand (Berlin; London: Springer, 2010); Hans Joachim Giessmann, "Fundamentalism, Extremism, Terrorism : Commonalities, Differences and Policy Implications Of "Blacklisting"," in The Routledge Handbook of International Crime and Justice Studies, ed. Bruce Arrigo and Heather Bersot (London [etc.]: Routledge, 2014), pp.516-538; Michael Price, Robert Rubinstein, and David Price, "'Material Support' : US Anti-Terrorism Law Threatens Human Rights and Academic Freedom," Anthropology today 28 , no. 1 (2012), pp.3-5.

${ }^{6}$ Michael Levi, "Combating the Financing of Terrorism: a History and Assessment of the Control of 'Threat Finance'," British Journal of Criminology 50, no. 4 (2010), pp.650-659.

${ }^{7}$ Andrew Philips, "The Wars on Terror, Duelling Internationalisms and the Clash of Purposes in a Post-Unipolar World," International politics 50, no. 1 (2013), pp. 77-96.
} 
${ }^{8}$ Freedman, "Officially Blacklisted Extremist/Terrorist (Support) Organisations", pp. 46-52.

${ }^{9}$ Philips, "The Wars on Terror", pp. 77-96.

${ }^{10}$ Freedman, "Officially Blacklisted Extremist/Terrorist (Support) Organisations", pp.46-52.

11 Australian Government, "Listing of Terrorist Organisations,", accessed 03 February 2014, http://www.nationalsecurity.gov.au/agd/WWW/NationalSecurity.nsf/Page/What_Governments_are_doingList ing_of_Terrorism_Organisations; Embassy of People's Republic of China in US, "China Seeks International Support in Counter-Terrorism," accessed 03 February 2014, http://www.chinaembassy.org/eng/xw/t56257.htm; Government of Canada, "Currently Listed Entities," accessed 03 February 2014, http://www.publicsafety.gc.ca/cnt/ntnl-scrt/cntr-trrrsm/lstd-ntts/crrnt-Istd-ntts-eng.aspx; Russian Federal Security Service, "Single Federal List of Foreign and International Terrorist Organisations Recognized by Russian Courts," accessed 03 February 2014, http://www.fsb.ru/fsb/npd/terror.htm; U.K. Home Office, "Proscribed Terror Groups or Organisations," accessed 03 February 2014, https://www.gov.uk/government/publications/proscribed-terror-groups-or-organisations--2; U.S. Department of State, "Foreign Terrorist Organisations," accessed 03 February 2014, http://www.state.gov/j/ct/rls/other/des/123085.htm.

${ }^{12}$ Alexander Horne and Diana Douse, "The Terrorism Act 2000: Proscribed Organisations," ed. Home Affairs Section (House of Commons Library, 2013).

${ }^{13}$ Johnson, Kevin R. "The Antiterrorism Act, the Immigration Reform Act, and Ideological Regulation in the Immigration Laws: Important Lessons for Citizens and Noncitizens," St. Mary's Law Journal 28 (1996): pp.838839.

${ }^{14}$ Anne L. Clunan, "The Fight against Terrorist Financing," Political Science Quarterly 121, no. 4 (2006), p.575; U.S. Department of State, "Foreign Terrorist Organisations."

${ }^{15}$ UN Security Council, "Resolution 1267," (1999).

${ }^{16}$ Jeanne Giraldo, Harold Trinkunas, and Barry Zellen, "Terrorism Financing and State Responses in Comparative Perspective", in Center for Contemporary Conflict (ed.), (Monterey, 2004); Elspeth Guild, "The Uses and Abuses of Counter-Terrorism Policies in Europe: The Case of the Terrorist List," Journal of Common Market Studies 46, no. 1 (2008), p.174; Haspeslagh, "Listing Terrorists", p.192.

${ }^{17}$ UN Security Council, "Resolution 1373," (2001).

${ }^{18}$ Conte, Human Rights in the Prevention and Punishment of Terrorism Commonwealth Approaches", p.586."; Levi, "Combating the Financing of Terrorism"p.653; McCulloch and Pickering, "Suppressing the Financing of Terrorism Proliferating State Crime", p.476; Martin Rudner, "Hizbullah Terrorism Finance: Fund-Raising and Money-Laundering," Studies in Conflict \& Terrorism 33, no. 8 (2010), p.708; Jonathan Winer, "Countering Terrorist Finance: A Work, Mostly in Progress," The Annals of the American Academy of Political and Social Science 618, no. 1 (2008), p.121.

${ }_{19}$ Freedman, "Officially Blacklisted Extremist/Terrorist (Support) Organisations", p.46; Peter Romaniuk, "Institutions as Swords and Shields : Multilateral Counter-Terrorism since 9/11," Review of international studies 36, no. 3 (2010), p.612.

${ }^{20}$ Peter Chalk, "The Tigers Abroad:How the LTTE Diaspora Supports the Conflict in Sri Lanka," Conflict and Security 9, no. 2 (2008), p.98.

${ }^{21}$ William VIcek, "Development Vs. Terrorism: Money Transfers and EU Financial Regulations in the UK," BJPI The British Journal of Politics \& International Relations 10, no. 2 (2008), p.290.

${ }^{22}$ Chalk, "The Tigers Abroad", p.103.

${ }^{23}$ Clunan, "The Fight against Terrorist Financing."p.573; Romaniuk, "Institutions as Swords and Shields", p.594595; Karthika Sasikumar, "State Agency in the Time of the Global War on Terror : India and the Counter-Terrorism Regime," Review of international studies 36, no. 3 (2010), p.617; Takashi Terada, "The US Struggles in APEC's Trade Politics: Coalition-Building and Regional Integration in the Asia-Pacific," Int. Negot. International Negotiation 18, no. 1 (2013), pp.49-66.

${ }^{24}$ Daniel Byman, "US Counter-Terrorism Options: A Taxonomy," Survival 49, no. 3 (2007), p.145.; Philips, "The Wars on Terror"p.92.

${ }^{25}$ Romaniuk, "Institutions as Swords and Shields", p.594.

${ }^{26}$ Byman, "US Counter-Terrorism Options."p.140.

${ }^{27}$ Ibid., p.137; Angel Rabasa et al., Beyond Al-Qaeda, vol. 2 (Santa Monica, CA: Rand Corp., 2006), p.83.

${ }^{28}$ Chalk, "The Tigers Abroad", p.98.

29 Ibid., p.99; Vlcek, "Development vs. Terrorism", p.290.

${ }^{30}$ Chalk, "The Tigers Abroad", p.103.

${ }^{31}$ Sasikumar, "State Agency in the Time of the Global War on Terror", p.617.

${ }^{32}$ Romaniuk, "Institutions as Swords and Shields", p.595. 
33 Byman, "US Counter-Terrorism Options", p.140.

${ }^{34}$ Philips, "The Wars on Terror", p.92.

${ }^{35}$ Romaniuk, "Institutions as Swords and Shields", p.596; Terada, "The US Struggles in APEC's Trade Politics", p.53.

${ }^{36}$ Philips, "The Wars on Terror", p.92-93.

37 Byman, "US Counter-Terrorism Options", p.140.

${ }^{38}$ Rabasa et al., Beyond Al-Qaeda, p.52.

${ }^{39}$ Byman, "US Counter-Terrorism Options", p.140.

${ }^{40}$ Rabasa et al., Beyond Al-Qaeda, p.48-117; Santos, "Counter-Terrorism and Peace Negotiations with Philippine Rebel Groups", p.143; Andrew Tan, "The US and China in the Malay Archipelago," Asia-Pacific Review 17, no. 2 (2010), p.30.

${ }^{41}$ Bahar Baser and Ashok Swain, "Diasporas as Peacemakers: Third Party Mediation in Homeland Conflicts," International Journal on World Peace 25, no. 3 (2008), p.11; Michael Johnsson and Svante Cornell, "Countering Terrorist Financing, Lessons from Europe," Conflict and Security 8, no. 1 (2007), p.71; Rudner, "Hizbullah Terrorism Finance", p.701; Winer, "Countering Terrorist Finance", p.115

${ }^{42}$ Rabasa et al., Beyond Al-Qaeda, p.2.

${ }^{43} \mathrm{McC}$ ulloch and Pickering, "Suppressing the Financing of Terrorism Proliferating State Crime", p.476; Romaniuk, "Institutions as Swords and Shields", p.598.

${ }^{44}$ Levi, "Combating the Financing of Terrorism", p.652-654; Romaniuk, "Institutions as Swords and Shields", p.604.

45 Terada, "The US Struggles in APEC's Trade Politics", p.50.

${ }^{46}$ Winer, "Countering Terrorist Finance", p.113.

${ }^{47}$ Byman, "US Counter-Terrorism Options", p.137; Rabasa et al., Beyond Al-Qaeda, p.83.

${ }^{48}$ Giessmann, "Fundamentalism, Extremism, Terrorism ", p.532.

${ }^{49}$ Haspeslagh, "Listing Terrorists", p.200; McCulloch and Pickering, "Suppressing the Financing of Terrorism Proliferating State Crime", p.476.

${ }^{50}$ Wyn Rees, Transatlantic Counter-Terrorism Cooperation: The New Imperative (London and New York: Routledge, 2006), p.33.

${ }^{51}$ Rabasa et al., Beyond Al-Qaeda, p.2.

${ }^{52}$ Chalk, "The Tigers Abroad", p.101; Rabasa et al., Beyond Al-Qaeda, p.110; Vlcek, "Development Vs. Terrorism", p.292.

53 Christine Fair, "Diaspora Involvement in Insurgencies: Insights from the Khalistan and Tamil Eelam Movements," Nationalism and Ethnic Politics 11, no. 1 (2005), pp.125-156.

${ }^{54}$ Marlies Casier, "Designated Terrorists: The Kurdistan Workers Party and Its Struggle to (Re)Gain Political Legitimacy," Mediterranean Politics 15, no. 3 (2010), p. 393-413; Östen Wahlbeck, "The Concept of Diaspora as an Analytical Tool in the Study of Refugee Communities," Journal of Ethnic and Migration Studies 28, no. 2 (2002), p.221-238.

${ }^{55}$ Rudner, "Hizbullah Terrorism Finance".

56 Philips, "The Wars on Terror", p.91; Romaniuk, "Institutions as Swords and Shields", p.596.

${ }^{57}$ Clunan, "The Fight against Terrorist Financing", p.576; Romaniuk, "Institutions as Swords and Shields", p.604.

${ }^{58}$ Javier Argomaniz, "Post-9/11 Institutionalisation of European Union Counter-Terrorism: Emergence, Acceleration and Inertia," European Security 18, no. 2 (2009), p.160-161.

${ }^{59}$ Vlcek, "Development vs. Terrorism", p.287.

${ }^{60}$ Guild, "The Uses and Abuses of Counter-Terrorism Policies in Europe", p.183.

${ }^{61}$ Casier, "Designated Terrorists", p.399-400.

62 Great Britain Parliament House of Commons Foreign Affairs Committee, UK-Turkey Relations and Turkey's Regional Role: Twelfth Report of Session 2010-12 : Report, Together with Formal Minutes, Oral and Written Evidence (London: Stationery Office, 2012), p.39.

${ }^{63}$ Rabasa et al., Beyond Al-Qaeda, p. 2-17.

${ }^{64}$ Bruce Vaughn, "Australia's Strategic Identity Post-September 11 in Context: Implications for the War against Terror in Southeast Asia," Contemporary Southeast Asia: A Journal of International and Strategic Affairs 26, no. 1 (2004), p. 95-98.

${ }^{65}$ Andrew O'Neil, "Degrading and Managing Risk: Assessing Australia's Counter-Terrorist Strategy," Australian Journal of Political Science 42, no. 3 (2007), p.474.

${ }^{66}$ Russell Smith, Rob McCusker, and Julie Walters, "Financing of Terrorism: Risks for Australia," Trends and Issues in Crime and Criminal Justice 394 (2010), pp.1-6. 
67 Jenelle Bonnor, "Australia-India: An Important Partnership," South Asian Survey South Asian Survey 15, no. 1 (2008), p.165-177.

${ }^{68}$ Christopher Michaelsen, "Australia and the Threat of Terrorism in the Decade after 9/11," Asian Journal of Political Science 18, no. 3 (2010), pp.248-268

69 Ibid., p.254; O'Neil, "Degrading and Managing Risk", p.472.

${ }^{70}$ Bonnor, "Australia-India", p.165; Vaughn, "Australia's Strategic Identity Post-September 11 in Context", p.107.

${ }^{71}$ Rabasa et al., Beyond Al-Qaeda, p.109.

72 Chalk, "The Tigers Abroad", p.100-101

73 Rudner, "Hizbullah Terrorism Finance", p.709.

${ }^{74}$ Michaelsen, "Australia and the Threat of Terrorism", p.256; David Rees, "Alternative Remittance Systems in Australia: Perceptions of Users and Providers," Trends and Issues in Crime and Criminal Justice, no. 393 (2010), p.3; Smith, McCusker, and Walters, "Financing of Terrorism", p.4.

75 Bonnor, "Australia-India", p.168-169; Michaelsen, "Australia and the Threat of Terrorism", p.249; O'Neil, "Degrading and Managing Risk", p.480; Vaughn, "Australia's Strategic Identity Post-September 11 in Context", p.100.

${ }^{76}$ O'Neil, "Degrading and Managing Risk", p.472; Terada, "The US Struggles in APEC's Trade Politics", p.60; Vaughn, "Australia's Strategic Identity Post-September 11 in Context", p.109.

77 Conte, Human Rights in the Prevention and Punishment of Terrorism Commonwealth Approaches, p.590.

${ }_{78}$ Davidson Smith, "Canada's Counter-Terrorism Experience," Terrorism and Political Violence 5, no. 1 (1993), p.86.

79 Ibid, p.88; Veronica Kitchen and Karthika Sasikumar, "Canada (En)Counters Terrorism: U.S.-Canada Relations and Counter-Terrorism Policy," Terrorism and Political Violence 21, no. 1 (2009), p.157.

${ }^{80}$ David Lewis, "The Failure of a Liberal Peace: Sri Lanka's Counter-Insurgency in Global Perspective," Conflict, Security \& Development 10, no. 5 (2010), p.659; Smith, "Canada's Counter-Terrorism Experience.", p. 104

${ }^{81}$ Rabasa et al., Beyond Al-Qaeda, p.149.

82 Kitchen and Sasikumar, "Canada (En)Counters Terrorism".

${ }^{83}$ Chalk, "The Tigers Abroad"

${ }^{84}$ Rudner, "Hizbullah Terrorism Finance"

${ }^{85}$ Ibid., p.709.

${ }^{86}$ Kitchen and Sasikumar, "Canada (En)Counters Terrorism", p.158; McCulloch and Pickering, "Suppressing the Financing of Terrorism Proliferating State Crime", p.476; Romaniuk, "Institutions as Swords and Shields", p.610; Santos, "Counter-Terrorism and Peace Negotiations with Philippine Rebel Groups.", p.143.

${ }^{87}$ Sharyl Cross, "Russia's Relationship with the United States/NATO in the US-Led Global War on Terrorism," The Journal of Slavic Military Studies 19, no. 2 (2006), p.189.

${ }^{88}$ Ibid., p.177.

${ }^{89}$ Abbas Osmayev, "The Chechen Republic: From 'Counter-Terrorist Operation' to Peacce (1999-2005)," in Chechen Scholars on Chechenya, ed. Julie Wilhelmsen and Erika Fatland (Oslo: Norwegian Institute of International Relations, 2008), p.29.

${ }^{90}$ Bakhtawar Mal Jain, "India and Russia : Reassessing the 'Time Tested' Ties," Pacific affairs. 76, no.3 (2003), p.388.

${ }^{91}$ Pavel Baev, "Putin's Counter-Terrorism: The Parameters of a Strategic Dead-End," Small Wars \& Insurgencies 17, no. 1 (2006), pp.10-11.

92 "Turning Counter-Terrorism into Counter-Revolution: Russia Focuses on Kazakhstan and Engages Turkmenistan," European Security 15, no. 1 (2006), p.16.

${ }^{93}$ Cross, "Russia's Relationship with the United States/NATO", p.178-179.

${ }^{94}$ Baev, "Turning Counter-Terrorism into Counter-Revolution", p.15; Dov Lynch, "The Enemy Is at the Gate:Russia after Beslan," International Affairs 81, no. 1 (2005), p.149-151; Philips, "The Wars on Terror", p.88; Sasikumar, "State Agency in the Time of the Global War on Terror", p.632.

${ }^{95}$ Baev, "Putin's Counter-Terrorism", p.2; Cross, "Russia's Relationship with the United States/NATO", p.183; Lynch, "The Enemy Is at the Gate", p.153.

96 Rabasa et al., Beyond Al-Qaeda, p.31.

${ }^{97}$ Lewis, "The Failure of a Liberal Peace", p.659; Tan, "The US and China in the Malay Archipelago", p.27; Terada,

"The US Struggles in Apec's Trade Politics", p.53

${ }^{98}$ Rashid Ahmad Khan, "Pakistan and China: Cooperation in Counter-Terrorism," Strategic Studies 32/33, no. 4/1 (2012), p.71 
${ }^{99}$ Dewardric McNeal, "China's Relations with Central Asian States and Problems with Terrorism," ed. Library of Congress Congressional Research Service ([Washington, D.C.]; Bethesda, MD: Congressional Research Service [Library of Congress], 2001), p.9-12.

${ }^{100}$ Baev, "Turning Counter-Terrorism into Counter-Revolution", p.9-10; McNeal, "China's Relations with Central Asian States and Problems with Terrorism", p.5; Tan, "The US and China in the Malay Archipelago", p.27.

101 Philips, "The Wars on Terror", p.89; Sasikumar, "State Agency in the Time of the Global War on Terror ", p.629.

${ }^{102}$ McNeal, "China's Relations with Central Asian States"; Philips, "The Wars on Terror", p.90

${ }^{103}$ Philips, "The Wars on Terror", p.88 